\title{
COMPANY RELEVANT STAKEHOLDERS’ RESPONSIBILITY: AN INNOVATIVE FORM OF RESPONSIBLE GOVERNANCE
}

\author{
Ovidiu NICOLESCU ${ }^{a *}$, Ciprian NICOLESCU \\ ${ }^{a}$ Management Academic Society in Romania, Romania, \\ ${ }^{a, b}$ Bucharest University of Economic Studies, Romania
}

\begin{abstract}
Corporate social responsibility has been one of the main approaches used in order to cope with the needs of society and grand societal challenges. Starting from corporate social responsibility and other approaches, this study proposes an innovative approach - company stakeholders' relevant responsibility. Based on three new concepts - relevant stakeholder, relevant responsibility and pentagon of relevant responsibilities - company stakeholders' relevant responsibility, by concomitantly focusing on the relevant issues and by extending beyond the corporation, to all types of companies' relevant responsibilities, could generate significant multifaceted advantages. In addition to increasing the capacity of companies to successfully take societal needs into consideration, this innovative type of responsible governance enhances the competitive multidimensional performance of the organization and its main internal and external stakeholders.
\end{abstract}

KEYWORDS: company relevant stakeholders responsibility, corporate social responsibility, grand societal challenges, relevant stakeholder, responsible governance

\section{INTRODUCTION}

In the last years, some innovative approaches of corporate social responsibility have been shown to be very interesting and useful, such as the politicized concept of corporate social responsibility (e.g. Djelic \& Etchanchu, 2017; Lyon et al., 2018; Scherer \& Palazzo, 2011; Scherer et al., 2016; Schrempf-Stirling et al., 2016) and company stakeholders' responsibilities (e.g. Freeman et al., 2010). These examples of responsible innovations have stimulated and helped us to try another innovative approach to organization responsibility from another perspective - company relevant stakeholders' responsibility. In this study, we present the content of this concept based on the analysis of corporate social responsibility and organization stakeholder theory and practice, using the new concepts - relevant stakeholders, relevant responsibility and pentagon of responsibilities. Company relevant stakeholders' responsibility, by its nature and content, is open to the grand societal challenges, based on the interests and contributions of the main stakeholders.

\section{REVIEW OF THE CORPORATE SOCIAL RESPONSIBILITY LITERATURE}

\subsection{Main CSR approaches}

Corporate social responsibility has a long history, starting from the end of the 19th century, but the major development of modern corporate social responsibility could be traced back to the 1960s and 1970s (Freeman et al., 2010). Corporate social responsibility has been defined and approached in a large variety of ways. Wang (2015) summarized the main contributions to the definitions of corporate social responsibility and corporate social responsibility related concepts, grouping them

\footnotetext{
${ }^{*}$ Corresponding author. E-mail address: inst.manager@gmail.com
} 
into four main categories: corporate social responsibility, corporate social performance, corporate citizenship and corporate philanthropy. In the first category - corporate social responsibility - four types of approaches have been identified. The integrative approach is the most used and the most important, being based on the systemic vision. The other three approaches of corporate social responsibility are oriented on certain types of problems - economic, voluntary and public - each of them important, but neglecting the other essential aspects of corporate social responsibilities.

\subsection{Carroll's pyramid of CSR}

Carroll's approach (1991), reflected in the pyramid of corporate social responsibilities, is the most known, disseminated and used integrative approach to corporate social responsibility. For this reason, we present it below. The Carroll pyramid, based on his corporate social responsibility definition from 1979, was published in 1991 (Carroll, 1979; Carroll, 1991). According to Carroll (1991), corporate social responsibilities encompass the economic, legal, ethical and discretionary (philanthropic) expectations that society has of organizations at a given point of time. The definition contains a set of four responsibilities, which create a framework that helps to characterize the nature of companies' responsibilities to society.

- Economic responsibility is a fundamental condition of businesses' existence that permits them to be created, to survive and to be sustained. Society expects and requires that companies be able to sustain themselves and this would not be possible without being profitable. A company needs profit in order to reward the owners and to reinvest for growth, making more products, services and value added. Economic responsibility is a baseline requirement without which the company cannot exist in a competitive economy;

- Legal responsibilities reflect the society's view of "codified ethics", containing the laws and regulations, mandatory to the company. Laws and regulations incorporate the fundamental notions of fair business practices and complying with them is a condition of operating in business;

- Ethical responsibilities reflect the society's expectations regarding the activities, norms, standards and practices, which companies should respect when they operate and conduct their affairs. Society's ethical requirements are in addition to previsions of laws and regulations. Ethical responsibilities mean a full range of norms, standards, values, principles and expectations of what consumers, community, company employees and owners regard as normal to the protection of stakeholders' moral rights;

- Philanthropic responsibilities deal with all forms of company giving, embracing voluntary or discretionary. Company philanthropic actions do not represent a responsibility in a literal sense. They represent a company response to the public expectations that the organization is a "good citizen". Fulfilment of the philanthropic responsibilities involves a variety of forms of giving products and services, donations, gifts of monetary resources, organization of employees' voluntarism, etc.

Later, Archie Carroll made several changes to his corporate social responsibility definition and pyramid (Carroll, 1999, Carroll 2004, Carroll 2016), but the most frequently used remains the variants from 1979 and 1991 (Carroll 1979; Carroll, 1991).

\subsection{Baden's pyramid of CSR}

Analysis using a comprehensive empirical basis (Baden, 2016) or deep evaluation (Sachs et al., 2009) have led certain specialists to argue that corporations cannot be seen as purely economic entities, detached from the individual. Denise Baden (2016, p. 3) consider that "corporate social responsibility is at heart primarily a moral concept designed to highlight the responsibilities of business, to avoid (as a minimum) causing harm to society and environment, or more proactively, 
contributing to the welfare of society and its stakeholders". She has proposed a new corporate social responsibilities pyramid, which becomes more powerful and effective by reordering the four types of responsibilities. The main practical conclusions are: a) the company, "in order to have license to operate and to be trusted with the production and allocation of scarce natural resources and inherently valuable human resources, it needs to first and foremost accept ethical responsibilities to not harm, and conform to society's ethic norms and expectations"; b) the company "needs to be compliant with legal responsibilities". The company is free to make profits and pursue its economic objectives only once it has accepted its moral and legal responsibilities.

\subsection{Implementation of CSR in companies}

During the last decades, concomitantly with the theoretical developments of corporate social responsibility, many companies - especially corporations - have implemented elements of corporate social responsibilities. Specialists' analysis have identified many elements in which significant progress has been made. We mention just a few of these aspects: the institutionalization of corporate social responsibility using certain social mechanisms (e.g. Bice, 2017); corporate social responsibility employing organizational models learning (e.g. Zadek, 2004); evaluation of employers' and employees' contributions to corporate social responsibility using the responsibility matrix (Haski-Leventhal et al., 2017); measuring corporate social responsibility employing a new tool conceived as a superordinate, multidimensional construct (El Akremi et al., 2018); design and use of special indexes for identifying corporate social responsibility initiatives (Lemonakis et al., 2017); construction of special models in order to determine the impact of social responsibility investment on the firm's market value (Mackey et al., 2007; Maon et al., 2010); relationships between intangibles productivity and corporate social performance (Hasan et al., 2018); types of congruence between organizations and their corporate social responsibility (De Jong \& Van der Meer, 2017); use of mechanisms that mediate the relationships between corporate social responsibility and corporate financial performance (Karaye et al., 2014); relationships between corporate social responsibility and employee engagement (Flammer \& Luo, 2017; Mirvis, 2012; Rampersad, 2017); connection between corporate social responsibility and corporate political responsibilities (Djelic \& Etchanchu, 2017; Lyon et al., 2018; Schrempf-Stirling et al., 2016); strategic corporate social responsibility (Chandler and Werther, 2014; Ghemawat, 2017; HaskiLeventhal, 2018). These indicate that the approach to corporate social responsibility is quite comprehensive, dealing with many important elements involved in corporate social responsibilities and company management.

\subsection{CSR and company stakeholders}

Eduard Freeman and his colleagues (Freeman et al., 2010) have identified two distinct lines of thought in the development of corporate social responsibility, from the perspective of stakeholder theory, for the integration of financial and social concerns that seem to proceed academic research and managerial practice: a) the residual view of corporate social responsibility, which is the initial view on it and is still predominant in theory and practice. The residual view conceptualizes corporate social responsibility as a nonstrategic activity, by giving back to society some of the value that companies created, mainly as a moral obligation; b) the integrative view of corporate social responsibility, which conceptualizes it as the integration of social, ethical and environmental concerns, as a strategic activity.

The integrative view means a deep change in the approach to corporate social responsibility taking into consideration the multidimensionality of company stakeholders' management as strategic producers and claimants of the value created in the company.

As a result of their analysis, this group of specialists (Freeman et al., 2010, p. 343) have proposed "to replace corporate social responsibility with the company stakeholders' responsibilities". 
According to them, "the company signals all forms of value creation and trade, all business and nonprofit organizations". Their main arguments are the following: responsibilities are not contingent on the size and success of one type of organization, all companies should shoulder responsibilities; the main goal of corporate social responsibility is to create value for key stakeholders - not only for shareholders - and to fulfil the responsibilities to them; company responsibilities imply that business cannot be separated from ethics, because business ethics and societal considerations are interdependent and they should be integrated. Based on these arguments, they state that company stakeholder responsibility views business and society as intertwined, it looks not just at a cooperation, but at many forms of organizations and promotes a pragmatic view on managing relationships with all the organization's stakeholders, as a primary task to success (Freeman et al., 2010). Recently, continuing this approach, Eduard Freeman and Heather Elms (2018) argued that the social responsibility of business is to create value for stakeholders. That means its customers, suppliers, employees and communities, as well as its shareholders (Freeman and Elms, 2018).

\subsection{Main benefits and limits of the CSR approaches}

Corporate social responsibility implementation has generated - and this is the predominant view of specialists - many positive effects. Specialists from the International Institute for Sustainable Development (IISD, 2018) have elaborated a comprehensive list with corporate social responsibility benefits, structured into three categories: a) company benefits - improved financial performance, lower operating costs, enhanced brand image and reputation, increased sales and customer loyalty, greater ability to attract and retain employees, reduced regulatory oversight, access to capital, workforce diversity, product safety and decreased liability; b) benefits to the community and the general public - charitable contributions, employees' volunteer programmes, corporate involvement in community education, employment and home lessons programmes, product safety and quality; c) environment benefits - greater material recyclability, better product durability and functionality, greater use of renewable resources, integration of environment management tools into business, including life-cycle assessment and costing, environmental management standards and eco labelling (e.g. Gabrielli \& Ruggeri, 2019; Simion et al., 2019). Business realities revealed in many studies (e.g. Baden, 2016; Carroll, 2016; Djelic \& Etchanchu, 2017; Mirvis, 2012; Rampersad, 2017; Schrempf-Stirling et al., 2016; Wang, 2015; Zadek, 2004) show other practical elements which recommend a reconsideration of corporate social responsibility. We shall enumerate some of them: social corporate responsibility is implemented to a greater or lesser extent in a small number of corporations, especially from the UK, USA Canada and a few other developed countries; frequently not all the major elements incorporated in the corporate social responsibility concept are included in the application of corporate social responsibility by corporations; the corporation culture, usually, does not incorporate corporate social responsibility as a major element; the corporate social responsibility topic is not included, or only as a peripheral subject, in managerial and human resources training and development; many major stakeholders are not taken into consideration in the companies when applying corporate social responsibility; the present corporate social responsibility approach in companies is focused more on the processes involved and less on the stakeholders, on the persons, structures or organizations, which practically implement the necessary decisions, actions and behaviours. Corporate social responsibility does not direct major attention to societal challenges like poverty, inequality, ocean acidification and others. We could conclude (assert) that corporate social responsibility plays a positive role in the economy and society, generating some benefits. Unfortunately, the number of corporations and companies which implement some types of social responsibility is very small, the implication of their stakeholders is very low, their actions are not carried out systematically and this activity does not represent a strategic one for them (Popa et al., 2019). Corporate social responsibility in practice is only tangentially connected to the grand societal challenges of our times. 


\section{AN INNOVATIVE RESPONSIBLE GOVERNANCE}

In the following, we propose a new approach of stakeholders' responsibility, in order to overcome the limits of corporate social responsibility. Our approach based on the concept of Freeman and his colleagues "company stakeholders' responsibilities" is intended to forge new steps in trying to integrate some valuable contributions of the theory and practice of corporate social responsibility and of company stakeholders (Freeman et al., 2010). We propose a new vision regarding both company responsibility and stakeholders, taking into consideration the multiple problems associated with the grand societal challenges.

\subsection{Relevant stakeholder, the cornerstone of the new approach}

In the rich literature dealing with stakeholders, there are many approaches to the stakeholder concept. Recently, Miles (2017) has identified almost 600 stakeholder definitions. We shall use a definition which incorporates the major elements that are often used by numerous specialists (e.g. Berman \& Johnson-Cramer, 2017; Freeman, 1984; Freeman et al., 2010; Mitchell et al., 1997). A stakeholder is a person or a group of persons who has an interest or a stake in the company and its performance, which affect it and also could be affected by this. Each company has internal and external stakeholders (company managers, shareholders and executants, suppliers, customers, local communities, investors, etc.). Stakeholders' number and variety increase concomitantly with the company size, complexity, diversification, development, etc.

Each stakeholder deserves to be taken into consideration by the company, to receive attention and to develop relationships. The development of the relationship between the company and its stakeholders involves many complex elements: company resources and the time of managers, specialists and other company human resources, special management and negotiation skills, certain specific methods and techniques to deal with different types of stakeholders, open and flexible company organizational culture, company agility, etc. The availability of these elements, within each company is limited, especially resources and time. A company can afford to allocate and spend only a certain "quantity" on the development of the relationships with stakeholders. As a result, a company could not afford to "cultivate" and develop relationships with all stakeholders. The company should be selective, it needs to identify and select the most important stakeholders, to treat them differently, taking into consideration their influence on the company and the other significant individual, organizational and contextual aspects. The company should establish the relevance of its stakeholders.

Stakeholders' relevance could be defined as the direct and indirect substantial influence, actual and/or potential, which a stakeholder exercises now or it could later, on the company functionality, development and performance. This influence should be taken into consideration in order to achieve organizational competitivity and sustainability. Stakeholder relevance defines the major impact of the stakeholder in the company and their strong interlinks to be taken into consideration by the organization. The stakeholder relevance is always multidimensional - business, social, and ecological aspects - being the most prominent dimensions.

The company stakeholders could be divided into two categories according to their relevance: relevant stakeholders, who should receive special attention from the company management and approached as major factors, in order to determine the organisation survival and sustainable development; irrelevant stakeholders, who are not deserving, at least at present, of special attention from the company management.

Relevant stakeholders, comparative with other stakeholders ${ }^{[1]}$, present the following features: stronger interests in the company functionality, development and performance; greater interests and influence on society that need to be taken into consideration; stronger motivation for the development of intensive relationships with the company and for joint harmonized actions with it; 
greater availability for communication and co-working with the company in certain fields; possession of valuable knowledge and competences, which are necessary and/or important for the company (Nicolescu \& Nicolescu, 2014); use and/or ownership of other resources (financial, technical-material, human, etc.) necessary to the company in order to achieve its strategies and policies; more powerful impact of the stakeholder, because of all previous elements, on certain company activities and results.

The stakeholders' relevance is determined according to two categories of elements:

(a) The company's interests, characteristics and evolutions reflected in: vision and leadership of the top managers and the main company stakeholders on addressing society's needs; company strategy and policies; characteristics of the organization management system; managerial methods, techniques and procedures used in the company; organizational culture of the company and evolutions and tendencies of the company field and of the organization's current and potential markets.

(b) Stakeholders' interests, characteristics and potentials evaluated at the level of each stakeholder category and then, for the relevant stakeholder category, at the level of every stakeholder. The evaluation of stakeholders and the society relevance is based on a set of parameters, the most significant being the followings: the present and future major interests of the stakeholder, reflected in the stakeholder's strategy and policies, managerial, social and ecological approaches used in the relationships with the company, other organizations and society; the main features of the stakeholder behaviour, mainly towards the company involved; stakeholder availability for communication, collaboration, co-working and performance achievement with the company; legitimacy (Mitchell et al., 1997); power (Mitchell et al., 1997); and urgency involved (Mitchell et al., 1997).

The characteristics considered in order to determine stakeholder relevance are frequently modified their parameters. Consequently, the stakeholder's influence on the company is changing too, having a dynamic dimension. For this reason, the evaluation of the stakeholders' relevance should be repeated periodically, in order to take this dynamism into account.

Stakeholders' relevance, according to the convergence of the company's and stakeholders' main interests, and expectations to convergence and to the nature of the reciprocal impacts, could be divided into two categories: a) "constructive relevance", which is based on the convergence of the stakeholder, company and society main interests and expectations, having as background a consistent win-win relationship; this relevance generates an increase in the performance and the business and social satisfactions for the company and the stakeholder and society; b) "Protective relevance", involving significant differences between the interests of the company and the stakeholder, which is usually based on tough negotiation and finally has as a result, the protection of certain major interests involved, most frequently of ecological and social nature; from the business point of view this type of relevance quite often involves significant time and resources from the organization, which do not contribute to an increase in company performance, but facilitates the continuation of the organization's activity and, eventually, has a positive impact on its brand and on meeting society's needs. Based on its evaluation, company management is able to decide who are the relevant company stakeholders, both organizations and persons. It could be useful to evaluate the degree of the stakeholders' relevance, possible assigning several categories of relevance, such as very high, high and average. This could be useful in designing the future company management approach for each stakeholder, inclusive of the resource type and importance allocated to the stakeholder co-working, and the dimension and types of stakeholder contribution to the company functioning and development. Relevant stakeholder should represent a central actor in the company management, in all decisions and actions regarding the organization, because it determines decisively its work, performance and sustainability. Relevant stakeholder has a very pragmatic dimension enabling a much better use of the company's and stakeholders' resources and the development of effective and efficient relationships between the company, society and relevant 
stakeholders. Focusing on the relevant stakeholder concept is very useful in many fields, starting with company management, stakeholder approach and company social responsibility. The relevant stakeholder concept facilitates the prioritization and the selective approach of the company stakeholders, and the focus on the most important aspects influencing the organization, the stakeholder's work and performance, and the environmental and societal challenges.

\subsection{Relevant responsibilities - a new concept}

We propose a new concept - relevant responsibility - starting from the following main reasons:

- there are many approaches to corporate social responsibility, including numerous aspects that are sometimes complex and not enough rigorous, which make its successful implementation in companies difficult;

- the results generated so far in corporations by the implementation of social responsibility are modest, even controversial (Chandler \& Werther, 2014);

- in order to generate much better results, it is necessary for each company to have a pragmatic approach, able to determine the realistic identification and effective focus on the most important social responsibilities in the specific organizational and social context;

- social responsibilities relate to the relevant company stakeholders and should be correlated with their approaches;

- social responsibilities should not be limited only to corporations and large companies - the classical approach - they should be used in all companies, because it is essential for all of them to meet their social responsibilities.

Relevant responsibility takes into consideration all types of company social responsibility that meets the condition of being relevant. A responsibility is relevant when it meets the criteria incorporated in table 1.

Table 1. Main criteria for evaluation of the responsibility relevance

\begin{tabular}{|c|l|}
\hline & \multicolumn{1}{|c|}{ Relevance criteria } \\
\hline 1 & $\begin{array}{l}\text { The responsibility refers to a major "social" need of society, the company and/or the relevant stakeholder, generated } \\
\text { to a large extent by the grand societal challenges }\end{array}$ \\
\hline 2 & The responsibility could be economic, social, legal, moral and ecological \\
\hline 3 & $\begin{array}{l}\text { Responsibility accomplishment represents an important element, in order to assure the relationship continuity and the } \\
\text { stability between the company and relevant stakeholders }\end{array}$ \\
\hline 4 & $\begin{array}{l}\text { Meeting this responsibility requires from the company and the relevant stakeholders, specific decisions, actions and } \\
\text { behaviours, which consume substantial time, knowledge and other resources }\end{array}$ \\
\hline 5 & $\begin{array}{l}\text { Responsibility has - once fulfilled - a significant positive impact on major elements regarding the company and/or } \\
\text { relevant stakeholder: organizational performance, individual performance, degree of motivation of the persons } \\
\text { involved, environmental protection, social welfare, education, poverty, intellectual capital protection and valorisation, } \\
\text { prestige and reputation of the organization and individuals involved and others }\end{array}$ \\
\hline 6 & $\begin{array}{l}\text { Responsibility fulfilment contributes significantly to the sustainability of the company and of the relationships } \\
\text { between the organization and relevant stakeholder, to address some of the grand societal challenges }\end{array}$ \\
\hline
\end{tabular}

Source: the authors

Relevant responsibilities determined according to these criteria vary from one company to another, reflecting the specificity of the company relevant stakeholders, local community and the environment. Relevant responsibilities have a very concrete content, providing the necessary elements, to adopt a pragmatic approach. Identification of the relevant company responsibilities, together with the relevant stakeholders, represents a new background for the innovative and more performant approach to social responsibilities in companies. 


\subsection{Pentagon of company relevant responsibilities}

All the above elements represent reasons, in order to propose an alternative to Carroll's pyramid or to other pyramids (see for example Baden, 2016) of corporate social responsibilities responsibilities relevant pentagon of the company. Compared with the previous pyramids of corporate responsibilities, the company relevant responsibilities pentagon (figure 1) presents certain specific features:

(a) It is focused on the company, relevant stakeholders and relevant responsibilities;

(b) It eliminates the mechanical separation and the hierarchical ordering of social responsibilities;

(c) It has introduced relevant ecological responsibilities, taking into consideration the recent evolution in the world economy and science;

(d) It is based on the holistic approach, taking into consideration all main aspects of relevant responsibility in their systemic interdependences, connected to the company and its relevant stakeholders.

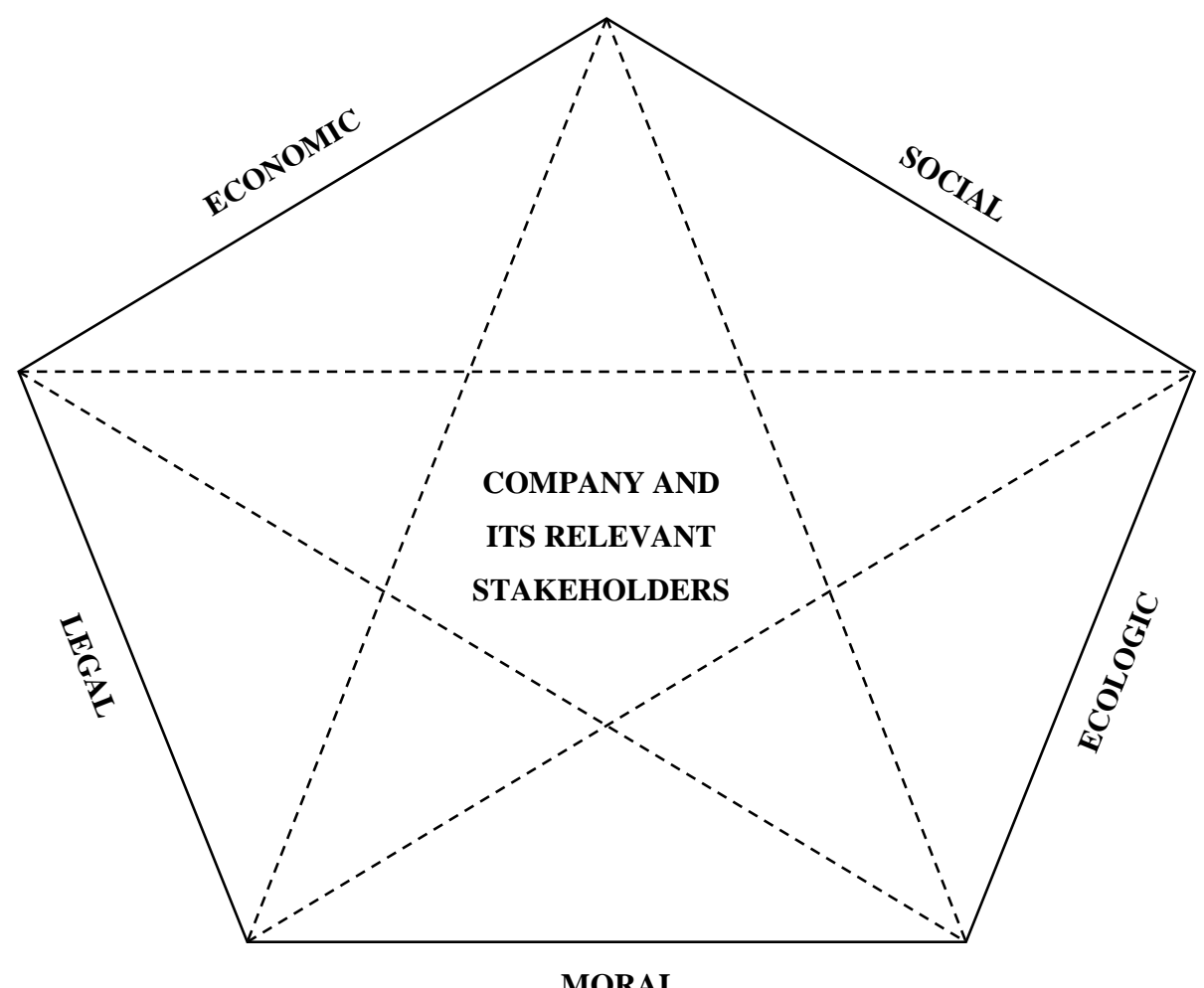

\section{Figure 1. Pentagon of company relevant stakeholders’ responsibilities}

Source: the authors

The pentagon of company relevant responsibilities represents a good background for a more comprehensive and pragmatic approach to social responsibilities in contemporary companies and their environment, and for addressing current and future grand societal challenges. In order to fully achieve this, a new systemic management mechanism is necessary, that is able to incorporate and fulfil the organizational and individual objectives, decisions, actions and behaviours, etc. involved in the five types of relevant responsibilities, according to the necessities and expectations of the company, and, internal and external relevant stakeholders. 


\subsection{Relevant company stakeholders’ responsibility: An innovative holistic vision and approach}

A new approach to social responsibility in companies should be holistic in all respects - vision, objectives, responsibilities, organizations, stakeholders and managerial mechanisms. We propose, based on the previous elements and other analysis, a variant of a new holistic organization of responsibilities, called company stakeholders' relevant responsibilities, which has the following features:

(a) It is focused on the new concept of relevant responsibilities, determined according to the criteria in table 1;

(b) It is based on the relevant responsibilities pentagon;

(c) Company relevant responsibility deals with every company's internal and external relevant stakeholders;

(d) Company relevant responsibilities are correlated with multi objectives of the company and its relevant stakeholders;

(e) Company relevant responsibilities take into consideration the relevant responsibilities according to their characteristics and not occasionally, when a crisis occurs, when it is a major pressure from powerful relevant stakeholders, etc.;

(f) Different types of responsibilities are correlated, taking into consideration their multidimensional nature, and the company, and the relevant stakeholders' multi objectives;

(g) Relevant responsibilities should be reflected in the relevant organizational and individual stakeholders' objectives, roles, tasks, competencies and responsibilities;

(h) Relevant responsibilities should be taken into consideration and implemented in all types of companies, regardless of their characteristics (size, profile, performance, location, etc.), because the content of the responsibilities reflects the major interests, objectives and necessities of the entire society, economy and population;

(i) Relevant responsibilities should be approached and implemented having in mind the particularities of each company (size, profile, age, technological level, performance, etc.) and of each relevant individual and organizational stakeholder;

(j) The company relevant responsibilities approach should be realistic and balanced, at least on two sides: the reasonable fulfilment of the relevant responsibilities of the company and the relevant stakeholders, and the enabling of the company's and relevant stakeholders' sustainability.

In table 2, we synthesized the main differences between corporate social responsibilities and company relevant stakeholders' responsibilities.

The concept of company stakeholders' responsibilities, through all its innovative characteristics, represents a new responsible governance scheme (Voegtlin and Scherer, 2017), which could respond, to a large extent, to the grand societal challenges at the level of companies - the largest group of organization in every economy.

Table 2. The main differences between corporate social responsibilities and company relevant stakeholders' responsibilities

\begin{tabular}{|c|l|l|l|}
\hline \multicolumn{1}{|c|}{ Elements } & Corporate social responsibilities & \multicolumn{1}{c|}{$\begin{array}{c}\text { Company relevant } \\
\text { stakeholders' responsibilities }\end{array}$} \\
\hline 1 & Type of organization & Corporation & All types of organization \\
\hline 2 & Type of responsibility & Social responsibility & $\begin{array}{l}\text { All types of relevant } \\
\text { responsibilities }\end{array}$ \\
\hline 3 & $\begin{array}{l}\text { Type of stakeholders taken } \\
\text { into consideration }\end{array}$ & $\begin{array}{l}\text { Certain primary corporation } \\
\text { stakeholders }\end{array}$ & $\begin{array}{l}\text { All relevant company } \\
\text { stakeholders }\end{array}$ \\
\hline 4 & Business objectives & $\begin{array}{l}\text { Mainly to create value for } \\
\text { company }\end{array}$ & $\begin{array}{l}\text { To create value for company } \\
\text { and company relevant }\end{array}$ \\
\hline
\end{tabular}


"Managing Sustainable Organizations"

$5^{\text {th }}-6^{\text {th }}$ November, 2020, BUCHAREST, ROMANIA

\begin{tabular}{|c|l|l|l|}
\hline \hline \multicolumn{1}{|c|}{ Elements } & Corporate social responsibilities & \multicolumn{1}{c|}{$\begin{array}{c}\text { Company relevant } \\
\text { stakeholders' responsibilities }\end{array}$} \\
\hline 5 & $\begin{array}{l}\text { Responsibilities to be } \\
\text { fulfilled }\end{array}$ & $\begin{array}{l}\text { Take care of some social } \\
\text { responsibilities toward certain } \\
\text { stakeholders }\end{array}$ & $\begin{array}{l}\text { All relevant organization } \\
\text { responsibilities and all relevant } \\
\text { stakeholders, according to the } \\
\text { main societal challenges }\end{array}$ \\
\hline
\end{tabular}

Source: the authors

\subsection{Innovative contributions of company relevant stakeholders' responsibilities, compared with company stakeholders' responsibilities}

Our approach - comparative with that of company stakeholders' responsibilities proposed by Freeman and his colleagues (Freeman et al., 2010) on which it is largely based - includes three new innovations:

(a) The relevant stakeholders' concept restricts the number of stakeholders taken into consideration by focusing on the most influential internal and external stakeholders. The relevant stakeholders are selected from among both internal and external stakeholders, including those which promote and could contribute to grand societal challenges. This selective approach to stakeholders provides a much more realistic stakeholder approach, taking into consideration the limited time and other resources which companies have and could use in dealing with stakeholders. Also, this innovative responsible governance multiplies the positive effects of the company's decisions and actions at the level of the most important internal and external stakeholders. Relevant stakeholders are approached as major actors in the construction, promotion and implementation of societal responsibilities and relevant responsibilities. As a result, the innovational intensity of all processes involved at the level of the company and each relevant stakeholder could increase to a large extent and also, the benefits generated.

(b) The relevant responsibilities concept and approach determine the focus on the most important responsibilities at the level of each company, its relevant stakeholders and social environmental context involved (local, territorial, national and/or international). Selection of the relevant responsibilities helps the focusing of the company and its relevant stakeholders on the most influential responsibilities in the specific context involved, so enabling more consistent positive effects. Relevant responsibilities established by intensive collaboration between the company and its relevant stakeholders, by win-win negotiation, have chances to be more realistic and pragmatic, to be able to increase significantly the degree of concrete contribution of each part (company and relevant stakeholders) to its successful implementation. The relevant responsibility approach helps the companies to be "more open" to society's needs at local, regional, national and international level.

(c) The pentagon of relevant responsibilities provides a larger set of types of responsibilities to be taken into consideration, by including specifically the ecological ones, which are becoming increasingly important at the current time. Moreover, the responsibilities pentagon proposes a quite different kind of relationships among the responsibilities considered, based on the systemic approach. The relevant responsibilities pentagon eliminates the artificial problems regarding what responsibilities are the most important, or how they should be correctly hierarchized. The pentagon of responsibilities is based on a holistic vision, treating each type of responsibility equally and taking into consideration all the reciprocal relationships between them in their interdependencies. Based on the pentagon of relevant responsibilities concept, each company could determine the relevant responsibilities more realistically, and could be more receptive to the contextual mega shifts, including the grand societal challenges.

These innovative elements incorporated in company relevant stakeholders' responsibilities provide better premises for the development of company responsibilities theory and practice, for generating better answers and solutions to the dynamic mega shifts and challenges of our times. 


\section{CONCLUSIONS}

\section{Theoretical contributions}

This study enriches the corporate social responsibility literature in five ways:

The first contribution is represented by the innovative company stakeholder relevant responsibility concept. In comparison with classical corporate social responsibility, it contains four new elements: it takes into consideration not only social responsibilities but other types of major responsibilities, including the ecological one; it is focused not on all social responsibilities, but only on the relevant ones, which are the most important in each company according to certain criteria; it extends the social responsibilities from the corporation to other types of companies; it takes into consideration the relevant internal and external stakeholders, individual and organizational, which are the main actors involved. Company stakeholders' relevant responsibility is based on and integrates three new concepts - relevant responsibility, the pentagon of relevant responsibilities and the relevant stakeholder.

Secondly, it introduces the relevant responsibility concept as a background to the social responsibilities approach. This determines the focus on essential societal needs, making better use of the resources available, which are always limited, and increasing the benefits for stakeholders.

Third, the responsibilities pentagon concept has been proposed as an alternative to the previous pyramids of responsibilities (e.g. Carroll, 1991; Baden, 2016). The responsibilities pentagon, based on a holistic vision, extends the responsibilities types considered, by taking into consideration the ecological one. Also, it replaces the hierarchy of responsibilities with a stellar type of interdependence, which better reflects the social and business realities and necessities.

The fourth contribution is the relevant stakeholder concept, which enables the focusing of decisions and actions regarding the social responsibilities on the most important internal and external company stakeholders, who are interested in cooperating with the organization. The relevant stakeholder approach avoids omitting the important stakeholders and, concomitantly, determines the allocation of time and other resources to meet the needs of the main organizational and individual "actors" involved.

Fifth, this study complements and extends the recent research studies on the politicized concept of corporate social responsibility (e.g. Scherer and Palazzo, 2011; Scherer et al., 2016) and stakeholder corporate responsibility (Freeman et al., 2010). We develop the social responsibility concept from another perspective, involving new aspects already mentioned in the previous paragraphs. Company stakeholders' relevant responsibility is an innovative responsible contribution of the governance type, trying to respond to the increasing necessities and the mega shifts in the society, at the level of companies and of the relevant stakeholders.

\section{Managerial implications}

Company stakeholders' relevant responsibilities, in order to become reality, to provide the necessary effects, should be integrated in company management. For this reason, it has many and deep implications on company management. We shall indicate the most important three implications, starting from the premise that corporate stakeholders' relevant responsibilities should represent a strategic field for the organization management.

First, stakeholders' relevant responsibilities means the company adopting new objectives, tasks, competences and responsibilities to be accomplished. In order to implement them, there are necessary changes in all the main elements of company management, in managers' and other internal and external stakeholders' decisions, actions and behaviours. It is recommended to start with the company vision and mission, which should have as a feature the promotion of the stakeholders' relevant responsibilities. Modifications should be introduced into company strategy and managerial mechanisms - organizational, informational, decisional, human resources, etc - in order to be able to fulfil all the new successfully elements associated with relevant stakeholders' 
responsibilities. Leadership and company culture need to incorporate stakeholders' relevant responsibilities as a permanent operational characteristic.

Second, stakeholders' relevant responsibilities determine a significant amplification of the openness of company management to the outside, to the external environment. There are, mainly, two reasons for this: company relevant responsibilities are generated to a large extent by the contextual evolutions, by the mega shifts and grand societal challenges: the numerous stakeholders customers, suppliers, investors, designers, consultants, local communities, NGOs, state administration bodies, etc. - and are external.

Third, in order to be able to implement successfully stakeholders' relevant responsibilities, company management should use the specific methods, techniques and procedures for the stakeholders' approach, focused on the relevant responsibilities. This essential problem could be solved in two ways: to reshape the present models, methods and techniques used by companies in the stakeholders' relationships according to the new requirements; to design new tools according to the relevant company stakeholders' concept. We mention that there are already numerous models, methods and techniques, which could be reshaped taking into account the new requirements, like a stakeholders' performance scorecard (e.g. Mitchell et al., 2015; Weber and Tarba, 2014); basic stakeholder analysis technique (e.g. Bryson et al., 2011; Fernández-Aráoz et al., 2017; Owen, 2003); stakeholder strategy matrix (e.g. Freeman et al., 2010; Westerman, 2018); social responsibility matrix (e.g. Haski-Leventhal, 2017; Sibony et al., 2017); stakeholders' co-creative network (e.g. Calton, 2015; Sawhney et al., 2006); analytical framework for collaborative planning processes (e.g. Haran \& Moore, 2014; Vandenbussche, 2017); and the six market model (e.g. Freeman et al., 2010; Weber \& Tarba, 2014).

The concept of company stakeholders' relevant responsibilities, which incorporates many innovative elements, involves a significant development, both in the management theory and practice. It could contribute to the new theory of the firm advocated by Scherer and Palazzo (2011).

\section{Future research areas}

Because company stakeholders' relevant responsibilities is a new approach, recently elaborated, there are many areas for which research is necessary and recommended. We select three areas, which we consider to be the priority at this stage.

First, research is necessary regarding the development of the company stakeholders' relevant responsibilities from the point of view of responsible governance (Scherer \& Palazzo, 2011).

Company stakeholders' relevant responsibilities need structures, procedures and other organizational elements in order to be fully and successfully implemented.

Second, a major area for research could be how to proliferate and develop company stakeholders' relevant responsibilities in different types of companies, taking into consideration their main characteristics, starting with organization size. Without a doubt, company stakeholders' relevant responsibilities should be reshaped differently in corporations, and large, middle and small enterprises. Their needs, resources, strengths and weaknesses are significantly heterogeneous and the types of approach and solutions should be differentiated.

The third area is the impact of the company stakeholders' relevant responsibilities on organization management theory and practice, It is essential to determine what are the main changes required in company management, so that company stakeholders' relevant responsibilities can be effectively implemented, without jeopardizing the organization's competitivity and sustainability. Company managerial processes, relationships and mechanisms should be reshaped in order to generate high benefits for company relevant stakeholders and relevant responsibilities, taking into account the grand societal challenges and the other deep changes in the economy and society.

\section{NOTES}

[1] We use the concept and the term relevant stakeholder and not "salient stakeholder" or "key stakeholder" (e.g. Graham, 2014; Mitchell et al., 1997) because: the relevant stakeholder is based 
on the relevant vision regarding the stakeholder, different from previous stakeholder conceptions; the relevance is specifically contextual, determined in the relationship with a certain company, certain category of stakeholder, certain stakeholder and -from a broader perspective - with a specific organization environment; the stakeholder relevance is determined in each company by evaluation of six parameters; the term "relevant", at least in our perception, presents a more consistent and constructive meaning than the term "salient", because relevance suggests the existence and implication of two or several parts; the relevance is always established by reference to certain elements. Of course, we know that the term "relevant stakeholder" has been used before, but to a small extent and, what is more important, in a quite different approach and context. We could cite Garcia-Castro (2015) and Aguilera et al. (2007) and Lelea et al. (2016).

\section{REFERENCES}

Aguilera, R.V., Rupp, D. E., Williams, C. A., \& Ganapathi, J. (2007). Putting the S back in corporate social responsibility: A multilevel model of social change in organizations. The Academy of Management Review, 32(3), 836-863. doi: 10.2307/20159338

Baden, D. (2016). A reconstructin of Carroll's pyramid of corporate social responsibility for $21 \mathrm{st}$ century. International Journal of Corporate Social Responsibility, 1(8). Retrieved October 21, 2020 ,

from https://www.academia.edu/33149703/A_reconstruction_of_Carrolls_pyramid_of_corporate_so cial_responsibility_for_the_21st_century

Bice, S. (2017). Corporate social responsibility as institution: A social mechanisms framework. Journal of Business Ethics, 143(1), 17-34. DOI: 10.1007/s10551-015-2791-1

Berman, S. L. \& Johnson-Cramer, M. E. (2017). Stakeholder theory: Seeing the field through the forest. Business \& Society, Social Issues in Management:The Distinction of Fields, 1-18.

Bryson, J., Patton, M. Q., \& Bowman, R. A. (2011). Working with evaluation stakeholders: A rationale, step-wise approach and toolkit. Evaluation and Program Planning, 34(1), 1-12. DOI: 10.1016/j.evalprogplan.2010.07.001

Calton, J. (2015). A decentred stakeholder network path to creating mutual value: Is Walmart showing the way?. The Journal of Corporate Citizenship, 2015(59), 82-91

Carroll, A. B. (1979). A three - dimensional conceptual model of corporate social performance. Academy of Management Review, 4(4), 497-505. DOI:10.2307/257850

Carroll, A. B. (1991). The pyramid of corporate social responsibility: Toward the moral management of organizational stakeholders. Business Horizons, 34(4), 39-48. DOI: 10.1016/0007-6813(91)90005-G

Carroll, A. B. (1999). Corporate social responsibility: Evolution of a definitional construct. Business \& Society, 38(3), 268-295. DOI: 10.1177/000765039903800303

Carroll, A. B. (2004). Managing ethically with global stakeholders: A present and future challenge. Academy of Management Executive, 18(2), 114-120. https://doi.org/10.5465/ame.2004.13836269

Carroll, A. B. (2016). Carroll's pyramid of CSR: Taking another look. International Journal of Corporate Social Responsibility, 1(3). Retrieved October 16, 2020, from https://doi.org/10.1186/s40991-016-0004-6

Chandler, D. \& Werther, B. W. (2014). Strategic corporate social responsibility: stakeholders, globalization and sustainable value creation, 3nd edition. Los Angeles, CA: Sage Publications.

De Jong, M. D. T. \& Van der Meer, M. (2017). How does it fit? Exploring the congruence between organizations and their corporate social responsibility (CSR) activities. Journal of Business Ethics, 143(1), 71-83. https://doi.org/10.1007/s10551-015-2782-2 
Djelic, M-L., \& Etchanchu, H. (2017). Contextualizing corporate political responsibilities: Neoliberal CSR in historical perspective. Journal of Business Ethics, 142(4), 641-661. https://doi.org/10.1007/s10551-015-2879-7

El Akremi, A., Gond, J-P., Swaen, V., De Roek, K., \& Igalens, J. (2018). How do employees perceive corporate responsibility? Development and validation of a multidimensional corporate stakeholder responsibility scale. Journal of Management, 44(2), 619-657. DOI: $10.1177 / 0149206315569311$

Fernández-Aráoz, C., Roscoe, A. \& Aramaki, K. (2017). Turning potential into success: The missing link in leadership development. Harvard Business Review, 95(6), 86-94

Flammer, C. \& Luo, J. (2017). Corporate social responsibility as an employee governance tool: evidence from a quasi-experiment. Strategic Management Journal, 38(2), 163-183. https://doi.org/10.1002/smj.2492

Freeman, R. E. (1984). Strategic management: A stakeholder approach. Boston, MA: Pitman

Freeman, R. E., Harrison, J. S., Wicks, A. C., Parmar, B. L., \& De Colle, S. (2010). Stakeholder Theory: The state of art. New York, NY: Cambridge University Press

Freeman, R. E. \& Elms, H. (2018). The social responsibility of business is to create value for stakeholders. MIT Sloan Management Review. Retrieved October 23, 2020, from https://sloanreview.mit.edu/article/the-social-responsibility-of-business-is-to-create-value-forstakeholders/

Gabrielli, L. \& Ruggeri, A. G. (2019). Developing a model for energy retrofit in large building portfolios: Energy assessment, optimization and uncertainty. Energy and Buildings, 202, 109356. DOI: 10.1016/j.enbuild.2019.109356

Garcia-Castro, R. \& Aguilera, R. V. (2015). Incremental value creation and appropriation in a world with multiple stakeholders. Strategic Management Journal, 36(1), 137-147. ttps://doi.org/10.1002/smj.2241

Ghemawat, P. (2017). Strategies for higher education in the digital age. California Management Review, 59(4), 56-78. DOI: 10.1177/0008125617717706

Graham, K. (2014). Five questions to identify key stakeholders. Harvard Business Review. Retrieved October 23, 2020, from https://hbr.org/2014/03/five-questions-to-identify-keystakeholders

Haran, U. \& Moore, D. A. (2014). A Better Way to Forecast. California Management Journal, 57(1), 5-15. https://doi.org/10.1525/cmr.2014.57.1.5

Hasan, I., Kobeissi, N., Liu, L., \& Wang, H. (2018). Corporate social responsibility and firm financial performance: The mediating role of productivity. Journal of Business Ethics, 149(3), 671-688. DOI: 10.1007/s10551-016-3066-1

Haski-Leventhal, D., Roza, L., \& Meijs, L. C. P. M. (2017). Congruence in corporate social responsibility: Connecting the identity and behavior of employers and employees. Journal of Business Ethics, 143(1), 35-51. https://doi.org/10.1007/s10551-015-2793-z

Haski-Leventhal, D. (2018). Strategic corporate social responsibility: Tools and theories for responsible management, 1st edition. London, UK: Sage Publications.

IISD (2013). Corporate social responsibility (CSR). Retrieved October 26, 2020, from https://www.iisd.org/business/issues/sr.aspx

Karaye, Y. I., Ishak, Z. \& Che-Adam, N. (2014). The mediating effect of stakeholder influence capacity on the relationship between corporate social responsibility and corporate financial performance. Procedia-Social and Behavioral Sciences, 164, 528-534. https://doi.org/10.1016/j.sbspro.2014.11.142

Lelea, M. A., Roba, G. M., Christinck, A., \& Kaufmann, B. (2016). “All relevant stakeholders": A literature review of stakeholder analysis to support inclusivity of innovation processes in farming and food systems. Paper presented at The 12th European International Farming Systems Association Symposium, Newport, UK 
Lemonakis, C., Garefalakis, A., Giannarakis, G., \& Konteos, G. (2017). The drivers of social responsible stock index: The case of Dow Jones sustainability index world. Corporate Ownership \& Control, 14(2), 173-180. DOI:10.22495/cocv14i2c1p3

Lyon, T. P., Delmas, M. A., Maxwell, J. W., Bansal, P., Chiroleu-Assouline, M, Crifo, P. et al. (2018). CSR needs CPR: Corporate sustainability and politics. California Management Review, 60(4), 5-24. https://doi.org/10.1177/0008125618778854

Mackey, A., Mackey, T. B., \& Barney, J. B. (2007). Corporate social responsibility and firm performance: Investor preferences and corporate strategies. The Academy of Management Review, 32(3), 817-835. https://doi.org/10.5465/amr.2007.25275676

Maon, F., Lindgreen, A., \& Swaen, V. (2010). Organizational stages and cultural phases: A critical review and a consolidative model of corporate social responsibility development. International Journal of Management Review, 12(1), 20-38. https://doi.org/10.1111/j.14682370.2009.00278.x

Miles, S. (2017). Stakeholder theory classification, definitions and essential contestability. In D. M. Wasieleski, \& J. Weber, (Eds), Stakeholder Management - Business and Society 360 (pp. 2147). Bingley, UK: Emerald Publishing Limited

Mirvis, P. H. (2012). Employee engagement and CSR: Transactional, relational, and developmental approaches. California Management Review, 54(4), 93-117. DOI: 10.1525/cmr.2012.54.4.93

Mitchell, R. K., Agle, B. R. \& Wood, D. J. (1997). Toward a theory of stakeholders identification and salience: Defining the principle of who and what really counts. The Academy of Management Review, 22(4), 853-886. DOI 10.2307/259247

Mitchell, R. K., Weaver, G. R., Agle, B. R., Bailey, A. D. , \& Carlson, J. (2015). Stakeholder agency and social welfare: Pluralism and decision making in the multi-objective corporation. The Academy of Management Review, 41(2), 252-275. https://doi.org/10.5465/amr.2013.0486

Nicolescu, O. \& Nicolescu, C. (2014). The specificity and typology of dynamic management studies. Journal of Organizational Change Management, 27(2), 299-313. DOI: $10.1108 / \mathrm{JOCM}-04-2013-0047$

Owen, D. L. (2003). Recent developments in European social and environmental reporting and auditing practice - A critical evaluation and tentative prognosis. Retrieved October 23, 2020, from http://citeseerx.ist.psu.edu/viewdoc/download?doi=10.1.1.203.5484\&rep=rep1\&type=pdf

Popa, S. C., Simion, C-P., Stefan, S. C., \& Albu, C. F. (2019). Strategy: A big challenge for a small business. Evidences from North-East Romanian SMEs. Economic Computation and Economic Cybernetics Studies and Research, 53(3), 169-186. DOI: 10.24818/18423264/53.3.19.10

Rampersad, R. (2017). Corporate social responsibility: Applying sustainability principles in stakeholder engagement. Corporate Ownership \& Control, 14(2-1), 222-229. DOI:10.22495/cocv14i2c1p8

Sachs, S., Rühli, E. \& Kern, I. (2009). Sustainable success with stakeholders: The untapped potential, 1st edition. Basingstoke, UK: Palgrave Macmillan.

Sawhney, M., Wolcott, R. C., \& Arroniz, I. (2006). The 12 different ways for companies to innovate. MIT Sloan Management Review, 47(3), 75-81

Scherer, A. G., \& Palazzo, G. (2011). The new political role of business in a globalized world: A review of a new perspective on CSR and its implications for the firm, governance, and democracy. Journal of Management Studies, 48 (4), 899-931. https://doi.org/10.1111/j.14676486.2010.00950.x

Scherer, A. G., Rasche, A., Palazzo, G., \& Spicer, A. (2016). Managing for political corporate social responsibility: New challenges and directions for PCSR 2.0. Journal of Management Studies, 53(3), 273-298. https://doi.org/10.1111/joms.12203

Schrempf-Stirling, J., Palazzo, G., \& Phillips, R. A. (2016). Historic corporate social responsibility. Academy of Management Review, 41(4), 700-719. https://doi.org/10.5465/amr.2014.0137 
Sibony, O., Lovallo, D., \& Powell, T. C. (2017). Behavioral strategy and the strategic decision architecture of the firm. California Management Review, 59(3), 5-21. https://doi.org/10.1177/0008125617712256

Simion, C-P., Nicolescu, C., \& Vrincut, M. (2019). Green procurement in Romanian construction projects. A cluster analysis of the barriers and enablers to green procurement in construction projects from the Bucharest-Ilfov region of Romania. Sustainability, 11(22), 1-25. DOI: $10.3390 /$ su1 1226231

Vandenbussche, L., Edelenbos, J., \& Eshuis, J. (2017). Pathways of stakeholders' relations and frames in collaborative planning practices: A framework to analyse relating and framing dynamics. Planning Theory, 16(3), 233-254. https://doi.org/10.1177/1473095215620150

Voegtlin, C. \& Scherer, A. G. (2017). Responsible innovation and the innovation of responsibility: Governing sustainable development in a globalized world. Journal of Business Ethics, 143(2), 227-243. DOI:10.1007/s10551-015-2769-z

Wang, S. (2015). Chinese strategic decision-making on CSR. Berlin Heidelberg: Springer Verlag

Weber, Y. \& Tarba, S. Y. (2014). Strategic agility: A state of the art introduction to the special section on strategic agility. California Management Review, 56(3), 5-12. https://doi.org/10.1525/cmr.2014.56.3.5

Westerman, G. (2018). Your company doesn't need a digital strategy. MIT Sloan Management Review, 59(3), 14-15

Zadek, S. (2004). The path to corporate responsibility. Harvard Business Review, 82(12), 125-132. 